\title{
Treatment of cashew extracts with Aspergillopepsin reduces IgE binding to cashew allergens
}

\author{
Cecily B. DeFreece ${ }^{1}$, Jeffrey W. Cary ${ }^{2}$, Casey C. Grimm², Richard L. Wasserman ${ }^{3}$, Christopher P Mattison ${ }^{2 *}$ \\ ${ }^{1}$ Department of Biology, Xavier University of Louisiana, New Orleans, LA, USA. \\ ${ }^{2}$ USDA-ARS, Southern Regional Research Center, New Orleans, LA, USA. \\ ${ }^{3}$ Allergy Partners of North Texas Research, Department of Pediatrics, Medical City Children's Hospital, Dallas, Texas, USA.
}

\section{ARTICLE INFO}

Article history:

Received on: $21 / 10 / 2015$

Revised on: 06/12/2015

Accepted on: 20/12/2015

Available online: 21/04/2016

Key words:

Aspergillus, cashew, food

allergy, immunoglobulin E, protease.

\begin{abstract}
Enzymes from Aspergillus fungal species are used in many industrial and pharmaceutical applications. Aspergillus niger and Aspergillus oryzae were cultured on media containing cashew nut flour to identify secreted proteins that may be useful as future food allergen processing enzymes. Mass-spectrometric analysis of secreted proteins and protein bands from SDS-PAGE gels indicated the presence of at least 63 proteins. The majority of these proteins were involved in carbohydrate metabolism, but there were also enzymes involved in lipid and protein metabolism. It is likely that some of these enzymes are specifically upregulated in response to cashew nut protein, and study of these enzymes could aid our understanding of cashew nut metabolism. Aspergillopepsin from A. niger was one of the proteolytic enzymes identified, and 6 distinct peptides were matched to this protein providing $22 \%$ coverage of the protein. Cashew extracts were incubated with a commercially available preparation of Aspergillopepsin (Acid Stable Protease, ASP) using simulated gastric fluid conditions to determine if ASP could degrade the protein and lower antibody binding to cashew allergens. Following treatment of cashew extract with ASP, a significant reduction was observed in cashew allergen binding to rabbit anti-cashew $\operatorname{IgG}$ using an immunoblot assay and serum IgE antibodies from cashew allergic individuals using competitive ELISA. These findings highlight the possible application of Aspergillopepsin/ASP from A. niger in food processing steps to attenuate cashew nut and other tree nut or peanut allergens.
\end{abstract}

\section{INTRODUCTION}

The incidence of food allergies in industrialized nations appears to be increasing, and there are no widely accepted therapies for food allergy sufferers. Up to $8 \%$ of children in the United States suffer from food allergy [1], and the self-reported frequency of peanut and tree nut allergies has increased over the past ten years [2]. Reactions to peanut and tree nuts are often severe and are rarely outgrown in adulthood [3] and can result in fatalities $[4,5]$. Very small amounts of a food allergen can cause a reaction [6,7], and estimates indicate that food allergy reactions are a significant cause of emergency room visits due to anaphylaxis $[8,9]$. The constant threat of accidental exposure places significant emotional, financial, and social burdens upon food allergy patients and their families $[10,11]$. The overall

* Corresponding Author

Christopher P. Mattison, Southern Regional Research Center, Agricultural Research Service, U.S. Department of Agriculture, 1100 Robert E. Lee Blvd., New Orleans, LA 70124, USA. Phone: (504) $286-$ 4392. Fax: (504) 286-4419. E-mail: chris.mattison@ars.usda.gov. economic burden associated with food allergy has been estimated at $\$ 25$ billion a year [12]. Development of new methods to disrupt the structure or sequence of the allergens present in tree nuts like cashews in order to reduce or eliminate the allergenic response would be beneficial. Cashew nuts can be part of a healthy and diverse diet, but may also be a food allergen in susceptible individuals. Food allergy, a Type I hypersensitivity mediated by immunoglobulin E (IgE) binding, can be a serious medical condition [13]. IgE binding to food allergens can result in various symptoms, and some studies have indicated that reactions to cashews are frequently severe $[14,15]$. Cashews, like other nuts, contain 3 conserved seed storage proteins that have been characterized as food allergens by the International Union of Immunological Societies (IUIS). These include the $7 \mathrm{~S}$ vicilin Ana o 1 [16], 11S legumin Ana o 2 [17], and the 2S albumin Ana o 3 [18]. Cashew allergens such as Ana o 1, Ana o 2, and Ana o 3 are resistant to physical and thermal processing methods [19, 20]. Several lines of evidence indicate that food preparation steps such as roasting can effect changes in nut allergens that modulate their ability to cause allergy. 
Enzymatic processing methods targeting food allergens have also been useful in lowering $\operatorname{IgE}$ binding to nut allergens, and several studies demonstrate the utility of enzymatic attenuation of nut allergens. For example, IgE binding to allergens from whole roasted peanuts and peanut flour has been effectively reduced following treatment with proteases [21-23]. Similarly, cashew proteins treated with pepsin have reduced IgE binding and have been used in cashew allergy immunotherapy using a mouse model $[24,25]$. While protease treatment of cashew allergens has proven useful, the application of these enzymes on a mass scale may be limited by the costs associated with production. As a consequence, the identification of novel proteases produced by microorganisms could be of great use given the applicability of the organisms to large-scale production [26]. Microorganisms that use plant seeds and nuts for sustenance have evolved specialized proteolytic enzymes that allow them to degrade plant proteins. Some of these enzymes have been utilized as food processing reagents for many decades, and fungal enzymes, particularly those from Aspergillus niger and Aspergillus oryzae, have proven to be some of the most important and long-standing reagents in the biotechnology field. A. niger and A. oryzae are both on the Food and Drug Administrations' (FDAs) Generally Regarded As Safe (GRAS) list. The Food and Agricultural Organization (FAO) and the World Health Organization (WHO) have repeatedly reviewed and accepted enzyme preparations from these fungi for food related applications and the fungi are used as hosts for the overproduction of recombinant food enzymes. Both A. niger and oryzae have been isolated as naturally occurring contaminants of cashew nuts [27, 28]. Previous work has shown that changes in growth media can have large effects on the profile of proteins that are secreted during fungal growth [29, 30]. For example, growth of Aspergillus species in the presence of collagen has been shown to induce expression of an alkaline protease [31], a fibrinogenolytic enzyme in the presence of peptone [32], and an esterase in the presence of sugar-beet pulp [33]. There are likely many as yet undiscovered applications for enzymes produced by Aspergillus and other microbial species awaiting discovery.

In the present study, cashew flour was incorporated into growth media to identify and characterize enzymes secreted by Aspergillus oryzae/niger during growth on cashew protein. The results indicated that Aspergillopepsin I/acid stable protease (ASP) is secreted by Aspergillus growing on media containing cashew flour and treatment of cashew extracts with ASP in vitro can reduce IgE binding. Continued study of aspergillopepsin and other microbiological enzymes or enzyme combinations may identify new applications for these enzymes in the food allergen processing arena and lead to methods to attenuate the allergenicity of nut proteins.

\section{MATERIALS AND METHODS}

\subsection{Materials}

Cashew nuts were purchased from Nuts Online (http://www.nuts.com, Cranford, NJ, USA). Purified porcine pepsin was purchased from Sigma Aldrich (St. Louis, MS, USA). Precast 10-20\% Tris-glycine SDS-PAGE gels were from Life Technologies (Carlsbad, CA, USA). Sequencing-grade modified trypsin was purchased from Promega (Madison, WI, USA). Biotinylated anti-human IgE antibody was purchased from Southern Biotech (Birmingham, AL, USA), and the IRdye-800CW labeled strepavidin from LI-COR (Lincoln, NE, USA). Maxisorp 96-well Nunc microtiter plates were purchased from ThermoScientific (Rochester, NY, USA). Defatted cashew flour was generated as described in Mattison et. al. [34]. Acid Stable Protease was donated from Bio-Cat Incorporated. (Troy, VA, USA). Human sera from cashew-allergic patients with a documented history of clinical cashew allergy were collected at Dallas-Allergy Immunology (Dallas, TX, USA). The study protocol was approved by the North Texas Institutional Review Board.

\subsection{Aspergillus culture Culture of $A$. oryzae and A. niger and secreted protein sample preparation}

Fungal conidia were collected with a solution of Triton $\mathrm{X}-100(0.01 \%)$ from the surface of colonies following 7 days growth at $30^{\circ} \mathrm{C}$ on potato dextrose agar (PDA, Difco). Conidia (approximately $10^{6} / \mathrm{ml}$ ) were used to inoculate $250 \mathrm{ml}$ peptone minimal salts broth (PMS; per liter: peptone, $50 \mathrm{~g}$; $\left(\mathrm{NH}_{4}\right)_{2} \mathrm{SO}_{4}, 3 \mathrm{~g}$; $\mathrm{KH}_{2} \mathrm{PO}_{4}, 10 \mathrm{~g} ; \mathrm{MgSO}_{4} \cdot 7 \mathrm{H}_{2} \mathrm{O}, 2 \mathrm{~g} ; 1 \mathrm{ml}$ micronutrient solution; $\mathrm{pH}$ 5.2) in 2 liter baffled flasks containing 5 g glass beads. Cultures were incubated for $17 \mathrm{~h}$ at $30^{\circ} \mathrm{C}$ in the dark with agitation at 200 rpm. Mycelia were collected by vacuum filtration through sterile miracloth and washed $1 \mathrm{X}$ with sterile water. Mycelia $(1 \mathrm{~g})$ were transferred to $50 \mathrm{ml}$ cashew flour broths (per $100 \mathrm{ml}: 0.5 \mathrm{~g}$ defatted cashew flour; $0.2 \mathrm{~g} \mathrm{MgSO}_{4} \cdot \mathrm{H}_{2} \mathrm{O} ; 0.1 \mathrm{ml}$ micronutrient solution; $\mathrm{pH} 5.2$ ) and $50 \mathrm{ml}$ glucose broths (cashew flour media with $5 \mathrm{~g}$ glucose replacing cashew flour/100 ml) in $250 \mathrm{ml}$ baffle flasks with $1 \mathrm{~g}$ glass beads. One aliquot of the cashew flour broth remained uninoculated as a control. Cultures were incubated in the dark at $30^{\circ} \mathrm{C}$ with agitation at $200 \mathrm{rpm}$ for $52 \mathrm{~h}$. Mycelia were collected by vacuum filtration through sterile miracloth, frozen in liquid nitrogen and stored at $-80^{\circ} \mathrm{C}$. Culture broths were collected and lyophilized for $72 \mathrm{~h}$ then resuspended in 2-3 $\mathrm{ml}$ sterile $\mathrm{ddH}_{2} \mathrm{O}$ and stored at $-80^{\circ} \mathrm{C}$.

\subsection{Sodium docecyl sulfate-polyacarylamide gel electrophoresis}

Secreted proteins were resolved on precast 10-20\% Trisglycine SDS-PAGE gels using a Novex Mini Cell apparatus (Life Technologies) and prestained Precision Plus molecular weight standards (Bio-Rad) were used as migration markers. NuPAGE LDS 4X sample buffer (Life Technologies) was added to the protein samples using a 1:4 (v/v) ratio, and samples were heated at $65{ }^{\circ} \mathrm{C}$ for $15 \mathrm{~min}$ prior to electrophoresis. Protein bands were visualized with Safe Stain (Invitrogen, Grand Island, NY, USA), and gel images were captured using the IRdye 680 channel of an Odyssey CLX infrared imaging system (LI-COR, NE, USA). 
2.4 Liquid chromatography coupled-mass spectrometry/massspectrometry

Samples of resuspended culture broths were analyzed by LC/MS/MS following precipitation with TCA. Equal amounts of secreted protein $(30 \mu \mathrm{g})$ from each culture were precipitated by the addition of ice-cold trichloroacetic acid to a final concentration of $10 \%$ and incubated on ice for 10 minutes. Samples were centrifuged at 20,000g for 30 minutes, and the resulting pellet was washed with acetone. Protein samples were reduced by the addition of $4 \mathrm{mM}$ dithiothreitol (DTT) in $50 \mathrm{mM}$ ammonium bicarbonate at $37{ }^{\circ} \mathrm{C}$ for 15 minutes and then alkylated by the addition of $15 \mathrm{mM}$ iodoacetamide for 30 minutes at room temperature in the dark. Protein pellets were dried under vacuum and then resuspended in $100 \mu \mathrm{l}$ of trypsin digestion buffer (100 $\mathrm{mM}$ ammonium bicarbonate, $1 \mathrm{mM}$ calcium chloride) containing $0.2 \mu \mathrm{g}$ trypsin per sample.

Following incubation at $37{ }^{\circ} \mathrm{C}$ for 24 hours, $1 \mu$ of formic acid was added to acidify the samples prior to LC-MS/MS analysis. Protein samples excised from SDS-PAGE gels were prepared and analyzed as described in Mattison et. al. [25]. Briefly, peptides extracted from gel slices were resuspended in 5\% formic acid and analyzed via liquid chromatography (LC) on an Agilent 1200 LC system, an Agilent Chip Cube interface, and an Agilent 6520 Q-TOF tandem mass spectrometer (Agilent Technologies, Santa Clara, CA, USA). Raw data files were extracted, sequenced, and searched against the SWISSPROT database to identify matching peptides using Spectrum Mill software (Agilent Technologies, Santa Clara, CA, USA).

\subsection{Cashew extract digestion}

Cashew extract samples $(10 \mu \mathrm{g})$ were subjected to digestion with the indicated amounts of acid stable protease $(5 \mu \mathrm{g}$, $4 \mathrm{SAPU} / \mathrm{mg})$ or pepsin $(0.02 \mathrm{ug}, 4000 \mathrm{U} / \mathrm{mg})$ in simulated gastric digestion buffer described in the United States Pharmacopeial Convention ( $35 \mathrm{mM} \mathrm{NaCl}, 84 \mathrm{mM} \mathrm{HCl}, \mathrm{pH} 1.2)$ [35]. Samples were removed at the indicated time points and digestion was stopped by adding Tris $\mathrm{pH} 8.5$ to $100 \mathrm{mM}$, PMSF to $1 \mathrm{mM}$, and placing the tubes on ice. For SDS-PAGE analysis $4 \mathrm{X}$ loading buffer was added to a final $1 \mathrm{X}$ concentration prior to gel loading.

\subsection{Immunoblotting}

Enzymatically treated cashew extract samples resolved on SDS-PAGE were transferred to a polyvinylidene difluoride (PVDF) membrane, and membranes blocked for $1 \mathrm{~h}$ at room temperature in phosphate buffered saline with $0.2 \%$ Tween-20 (PBST) with $2 \%(w / v)$ nonfat dry milk. Rabbit anti-cashew antibody [34] was diluted 1:1000 in PBST and incubated for $1 \mathrm{~h}$ at room temperature.

The membrane was washed four times for $5 \mathrm{~min}$ in PBST and then incubated for $30 \mathrm{~min}$ with anti-rabbit IRdye-800 (1:10000 in PBST) at room temperature. The membrane was washed as above and visualized using an Odyssey CLx (LI-COR, NE, USA) infrared imaging system. The data are plotted as the average of 3 independent experiments with standard deviation error bars.

\subsection{Competitive enzyme-linked immunosorbent assay}

Competitive ELISA to evaluate IgE binding in human sera with enzymatically treated or control cashew extracts was performed essentially as described in Mattison et. al. [25]. Enzymatically treated or control cashew extracts were serially

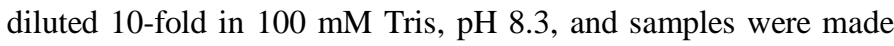
using $25 \mu \mathrm{L}$ of treated cashew sample, $25 \mu \mathrm{L}$ of pooled sera, and $50 \mu \mathrm{L}$ of $100 \mathrm{mM}$ Tris, $\mathrm{pH}$ 8.3. Mixed samples were incubated at $37^{\circ} \mathrm{C}$ for $2 \mathrm{hrs}$ in microtiter plates pre-coated with $1 \mu \mathrm{g}$ of cashew extract and blocked with PBST containing 1\% BSA. Plates were washed 4 times with $200 \mu \mathrm{L}$ of PBST, and biotinylated anti-IgE (1:1000 in PBST) was added to each well and then incubated at 37 ${ }^{\circ} \mathrm{C}$ for $1 \mathrm{hr}$.

Plates were washed with PBST, and $50 \mu \mathrm{L}$ of streptavidin-labeled IRdye-680 (1:5000 in PBST) was added to each well. Plates were incubated at $37^{\circ} \mathrm{C}$ for $30 \mathrm{~min}$, washed, and then imaged with the Odyssey CLx instrument. For figure $3 \mathrm{~A}$, the data in the plot are representative of duplicate independent experiments and are presented as percent of $\mathrm{IgE}$ inhibition using the following formula:

$1-\mathrm{A} / \mathrm{B}$

where A equals the IR800 value of inhibited sample, and B equals the IR800 value of uninhibited control with values expressed as a percentage rounded to the nearest integer. For Figure 3B, the data are plotted as the average of 4 independent experiments with the $0.001 \mathrm{mg} / \mathrm{ml}$ sample of digested cashew extract. Standard variation in IgE binding percentage is included as error bars in Figure 3B.

\section{RESULTS}

\subsection{LC-MS/MS analysis of bulk secreted proteins from} Aspergillus cultured on media containing cashew nut flour

In this study we tested whether fungi in the genus Aspergillus were capable of producing enzymes that hydrolyze cashew allergen proteins following exposure to cashew nut flour. Proteins secreted by each of the fungi after 24 hours of growth on media containing cashew nut flour were surveyed by LC/MS/MS. As shown in Table 1, following precipitation with TCA and sample treatment with trypsin we observed peptides that could be matched to 62 proteins involved in carbohydrate, lipid, and protein metabolism. This bulk analysis of proteins secreted into the growth media indicated the presence of 31 proteins involved in carbohydrate metabolism, 5 proteins involved in lipid metabolism, 14 proteolytic enzymes, and a single ribonuclease. There were also 11 proteins with various predicted functions including a glycosyl hydrolase, glucanase, glucanosyltransferase, glutaminase, ribonuclease, $\mathrm{N}$-acetylglucosaminidase, $\mathrm{S} 10$ peptidase, and serine carboxypeptidase. 
Table 1: Mass-spectrometric identification of bulk secreted proteins from Aspergillus species cultured on cashew nut flour containing media.

\begin{tabular}{|c|c|c|c|}
\hline Accession \#NCBI/ASPGD & Matching peptide \# & Functional group & $\begin{array}{r}\text { Protein [predicted] } \\
\end{array}$ \\
\hline 113496 & 4 & carbohydrate metabolism & alpha-galactosidase A \\
\hline 217807 & 5 & carbohydrate metabolism & alpha-amylase \\
\hline 1160313 & 6 & carbohydrate metabolism & glucoamylase \\
\hline 3023267 & 4 & carbohydrate metabolism & alpha-glucosidase \\
\hline 13810441 & 2 & carbohydrate metabolism & alpha-L-arabinofuranosidase A \\
\hline 74698498 & 4 & carbohydrate metabolism & 1,4-beta-D-glucan cellobiohydrolase B \\
\hline 94706960 & 13 & carbohydrate metabolism & 1,4-alpha-D-glucan glucanohydrolase \\
\hline 114794116 & 9 & carbohydrate metabolism & alpha-Amylase \\
\hline 121939500 & 3 & carbohydrate metabolism & mannosyl-oligosaccharide alpha-1,2-mannosidase \\
\hline 134080612 & 2 & carbohydrate metabolism & exo-inulinase inu 1 \\
\hline 159023686 & 3 & carbohydrate metabolism & fructosyltransferase \\
\hline 350630290 & 3 & carbohydrate metabolism & alpha-galactosidase extracellular \\
\hline 350631148 & 4 & carbohydrate metabolism & alpha-amylase A \\
\hline 350631594 & 2 & carbohydrate metabolism & 1,3-beta-glucanosyltransferase \\
\hline 350633017 & 4 & carbohydrate metabolism & 1,4-alpha-D-glucan glucohydrolase \\
\hline 350634958 & 2 & carbohydrate metabolism & arabinan endo-1,5-alpha-L-arabinosidase \\
\hline 350635004 & 2 & carbohydrate metabolism & alpha-galactosidase \\
\hline 350636225 & 3 & carbohydrate metabolism & alpha-L-arabinofuranosidase B \\
\hline 350638468 & 4 & carbohydrate metabolism & exo-1, 4-beta-xylosidase xlnD \\
\hline 350638529 & 2 & carbohydrate metabolism & alpha-glucosidase \\
\hline 350638537 & 2 & carbohydrate metabolism & glycosidase \\
\hline 350638658 & 3 & carbohydrate metabolism & alpha-mannosidase \\
\hline 350638806 & 2 & carbohydrate metabolism & glucooligosaccharide oxidase \\
\hline A2QAN3 & 3 & carbohydrate metabolism & beta-galactosidase $\mathrm{A}$ \\
\hline A2RAL4.1 & 2 & carbohydrate metabolism & beta-glucosidase A \\
\hline AFL2G_01841 & 5 & carbohydrate metabolism & alpha-amylase A type-3 \\
\hline P56271 & 5 & carbohydrate metabolism & acid alpha-amylase \\
\hline P56526 & 2 & carbohydrate metabolism & alpha-glucosidase \\
\hline P69327.1 & 5 & carbohydrate metabolism & glucoamylase \\
\hline P87076 & 2 & carbohydrate metabolism & beta-glucosidase $\mathrm{A}$ \\
\hline Q4AEG8.1 & 3 & carbohydrate metabolism & exo-1,4-beta-xylosidase \\
\hline 134077929 & 2 & hypothetical protein & 1,3-beta-glucanosyltransferase \\
\hline 350630620 & 2 & hypothetical protein & hypothetical protein \\
\hline 350631889 & 2 & hypothetical protein & DUF1237 domain protein \\
\hline 350632039 & 2 & hypothetical protein & hypothetical protein \\
\hline 350632918 & 2 & hypothetical protein & serine carboxypeptidase \\
\hline 350632924 & 2 & hypothetical protein & exo-beta-1,3-glucanase \\
\hline 350633230 & 2 & hypothetical protein & S10 peptidase \\
\hline 350635197 & 2 & hypothetical protein & glutaminase \\
\hline 350635684 & 2 & hypothetical protein & hypothetical protein \\
\hline 350638503 & 2 & hypothetical protein & ribonuclease $\mathrm{T} 2$ \\
\hline 350639912 & 2 & hypothetical protein & $\mathrm{N}$-acetylglucosaminidase \\
\hline 350633018 & 3 & lipid metabolism & extracellular lipase \\
\hline 350633410 & 3 & lipid metabolism & triacylglycerol lipase precusor \\
\hline 350633910 & 2 & lipid metabolism & GDSL lipase/acylhydrolase \\
\hline 350638842 & 2 & lipid metabolism & phospholipase C \\
\hline 350639908 & 2 & lipid metabolism & triacylglycerol lipase \\
\hline 133241 & 2 & nucleic acid metabolism & ribonuclease $\mathrm{T} 2$ \\
\hline 129235 & 5 & proteolysis & alkaline protease \\
\hline 3123246 & 2 & proteolysis & serine-type carboxypeptidase \\
\hline 121798407 & 4 & proteolysis & leucine aminopeptidase \\
\hline 121802887 & 3 & proteolysis & dipeptidyl peptidase 4 \\
\hline 121804190 & 5 & proteolysis & leucine aminopeptidase 2 \\
\hline 350629684 & 3 & proteolysis & S28 peptidase \\
\hline 350630288 & 3 & proteolysis & tripeptidyl-peptidase \\
\hline 350632613 & 4 & proteolysis & aorsin/S53 peptidase \\
\hline 350637380 & 2 & proteolysis & aspartic protease \\
\hline 350637842 & 2 & proteolysis & S8-S53 peptidase \\
\hline 350639368 & 3 & proteolysis & tripeptidyl peptidase \\
\hline 350639535 & 4 & proteolysis & aspergillopepsin A \\
\hline 666429641 & 2 & proteolysis & secreted dipeptidyl peptidase \\
\hline AFL2G_01995 & 3 & proteolysis & oryzin precursor \\
\hline
\end{tabular}

\subsection{Comparison of secreted proteins from the A. oryzae and A. niger cultures}

A comparison of the secreted proteins from the two Aspergillus cultures grown with media containing cashew flour indicated that many of the visible proteins secreted from the two fungi were unique to either A. oryzae or A. niger (Figure 1). Following SDS-PAGE there were 19 bands that appeared unique between the two cultures, and that were not visible in the uninoculated control. Secreted proteins were analyzed by LC/MS/MS following excision of discrete protein bands from the 
SDS polyacrylamide gels. Several bands from specific regions of the gel were removed from each lane (Figure 1) and the contents were reduced, alkylated, and trypsinized. Proteins having at least 3 matched peptides within the excised band are listed in Table 2. In some cases, such as the bands in between boxes 16 and 17, we were unable to identify proteins from the gel samples. Two proteins secreted from A. oryzae, migrated above the $100 \mathrm{kDa}$ marker that were not visible in the A. niger sample. One protein migrating near the $50 \mathrm{kDa}$ marker was particularly intense from the $A$. oryzae secreted sample, but was absent, or drastically reduced in intensity, from the A. niger sample. The $A$. niger sample contained a cluster of proteins migrating around the $75 \mathrm{kDa}$ marker that were not as visibly intense in the A. oryzae sample. From the A. niger culture, there were several enzymes involved in carbohydrate metabolism including alpha-amylase A, 1,4-alpha-D-glucan glucohydrolase, alpha-galactosidase A, exoinulinase, and alpha-L-arabinofuranosidase B (Table 2). Many of the higher molecular weight bands in the A. oryzae culture were also involved in carbohydrate metabolism including betagalactosidase, fructosyltransferase, glucoamylase, 1,4-alpha-Dglucan glucohydrolase, and alpha-amylase (Table 2). We also matched peptides indicating the presence of an extracellular lipase in slice 5. Peptides matching lipid metabolism proteins such as triacylglycerol were also present in gel slices 7,8 , and 9 . We were interested in identifying secreted fungal proteases that could degrade cashew nut seed storage proteins and limit the allergic potential of these proteins. Peptides were matched to 4 proteases; aspergillopepsin (GI 350639535)/acid stable protease (ASP), didpeptidyl peptidase 4 (121802887), leucine aminopeptidase (121798407), and an alkaline protease (129235) within slices 7 , 13, 17, and 19. Notably, there were 5 good matches to aspergillopepsin I/ASP (GI 350639535) peptides in gel slice number 7 migrating just below the $37 \mathrm{kDa}$ marker from the $A$. niger sample (Figure 1 and Table 2).

Analysis of several samples by SDS-PAGE and LC/MS/MS to confirm the presence of aspergillopepsin I/ASP from the corresponding band showed matches to 6 distinct aspergillopepsin I/ASP peptides covering $22 \%$ of the protein (Table 3). A search of the protein databases failed to identify matches for gel slice samples 10,11 and 18. None of the proteins identified in this analysis were present in the corresponding segment of the control lane.

Table 2: Mass-spectrometric identification of gel isolated secreted proteins from Aspergillus species cultured on cashew nut flour containing media.

\begin{tabular}{|c|c|c|c|c|c|}
\hline Gel Spot \# & Accession \#NCBI/ASPGD & Peptide \# & Function [predicted] & Protein [predicted] & MW \\
\hline 1 & 350631148 & 7 & carbohydrate metabolism & alpha-amylase A & 65230 \\
\hline 1 & 350633017 & 5 & carbohydrate metabolism & 1,4-alpha-D-glucan glucohydrolase & 70400 \\
\hline 1 & P28351.1 & 4 & carbohydrate metabolism & alpha-galactosidase A & 60148 \\
\hline 2 & 350631148 & 7 & carbohydrate metabolism & alpha-amylase A & 65230 \\
\hline 2 & 350633017 & 5 & carbohydrate metabolism & 1,4-alpha-D-glucan glucohydrolase & 70400 \\
\hline 2 & 134080612 & 4 & carbohydrate metabolism & exo-inulinase inu1 & 59070 \\
\hline 2 & 350630290 & 4 & carbohydrate metabolism & alpha-galactosidase extracellular & 59950 \\
\hline 3 & 350631148 & 8 & carbohydrate metabolism & alpha-amylase A & 65230 \\
\hline 3 & 350633017 & 7 & carbohydrate metabolism & 1,4-alpha-D-glucan glucohydrolase & 70400 \\
\hline 3 & 350630290 & 6 & carbohydrate metabolism & alpha-galactosidase extracellular & 59950 \\
\hline 3 & 113496 & 6 & carbohydrate metabolism & alpha-galactosidase A & 59950 \\
\hline 4 & 350631148 & 4 & carbohydrate metabolism & alpha-amylase A & 65230 \\
\hline 4 & 350633017 & 6 & carbohydrate metabolism & 1,4-alpha-D-glucan glucohydrolase & 70400 \\
\hline 5 & 350631148 & 6 & carbohydrate metabolism & alpha-amylase A & 65230 \\
\hline 5 & 350633018 & 4 & lipid metabolism & extracellular lipase & 61820 \\
\hline 5 & 350636225 & 4 & carbohydrate metabolism & alpha-L-arabinofuranosidase B & 54890 \\
\hline 6 & AFL2G_01841 & 6 & carbohydrate metabolism & alpha-amylase A type-3 & 54780 \\
\hline 6 & 350630290 & 4 & carbohydrate metabolism & alpha-galactosidase extracellular & 59950 \\
\hline 7 & 350633410 & 5 & lipid metabolism & triacylglycerol lipase precusor & 32670 \\
\hline 7 & 350639535 & 5 & proteolysis & aspergillopepsin & 43340 \\
\hline 8 & 350633410 & 4 & lipid metabolism & triacylglycerol lipase precusor & 32670 \\
\hline 9 & 350633410 & 4 & lipid metabolism & triacylglycerol lipase precusor & 32670 \\
\hline 10 & & & no match & & \\
\hline 11 & & & no match & & \\
\hline 12 & 528082121 & 3 & carbohydrate metabolism & beta-galactosidase & 110179 \\
\hline 13 & 121802887 & 3 & proteolysis & dipeptidyl peptidase 4 & 86875 \\
\hline 14 & 159023686 & 3 & carbohydrate metabolism & fructosyltransferase & 65230 \\
\hline 15 & 1160313 & 7 & carbohydrate metabolism & glucoamylase & 67320 \\
\hline 16 & 94706960 & 25 & carbohydrate metabolism & 1,4-alpha-D-glucan glucohydrolase & 54890 \\
\hline 16 & 114794116 & 24 & carbohydrate metabolism & alpha-amylase & 52580 \\
\hline 17 & 121798407 & 4 & proteolysis & leucine aminopeptidase & 41470 \\
\hline 18 & & & no match & & \\
\hline 19 & 129235 & 3 & proteolysis & alkaline protease & 44330 \\
\hline
\end{tabular}


Table 3: Aspergillus niger Aspergillopepsin peptides identified by mass-spectrometry.

\begin{tabular}{cccccc}
\hline$\#$ & peptide sequence & $\begin{array}{c}\text { peptide start amino acid } \\
\text { number }\end{array}$ & $\begin{array}{c}\text { m/z measured } \\
\text { [Da] }\end{array}$ & MH+ matched [Da] & MH+ error [ppm] \\
\hline 1 & {$[$ K]GSAVTTPQNNDEEYLTPVTVGK[S] } & 3 & 774.047 & 2320.13 \\
2 & {$[$ R]DTVTVGGVTTNK[Q] } & 87 & 596.316 & 1191.622 \\
3 & [K]AQTTFFDTVK[S] & 135 & 579.3016 & 1157.584 \\
4 & {$[$ K]SQLDSPLFAVQLK[H] } & 145 & 482.6051 & 1445.8 & -1.7 \\
5 & {$[$ K]HDAPGVYDFGYIDDSK[Y] } & 158 & 600.2645 & 1798.792 \\
6 & {$[$ K]SQYVVFNSEGPK[L] } & 307 & 677.8345 & 1354.664 \\
\hline
\end{tabular}

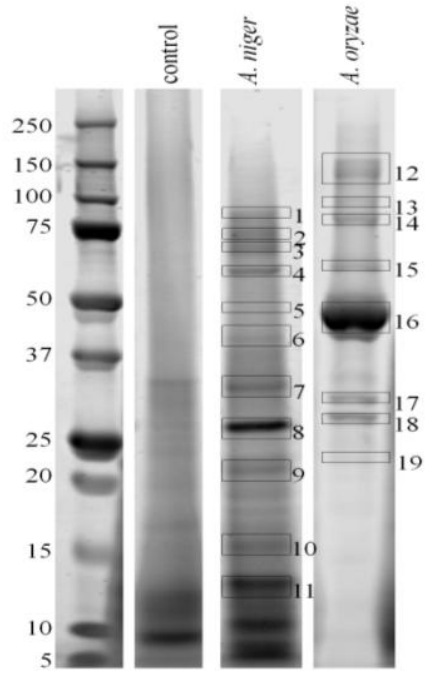

Fig. 1: Protein expression patterns observed in A. niger and A. oryzae following exposure to cashew nut flour during growth. A. niger and A. oryzae samples were grown in the presence of cashew nut flour for $24 \mathrm{hrs}$, the control is media with cashew nut flour that was not inoculated with fungi. Gel slices [indicated by numbered boxes] of specific protein bands from the secreted proteins of Aspergillus cultures were harvested for mass-spectrometric analysis.
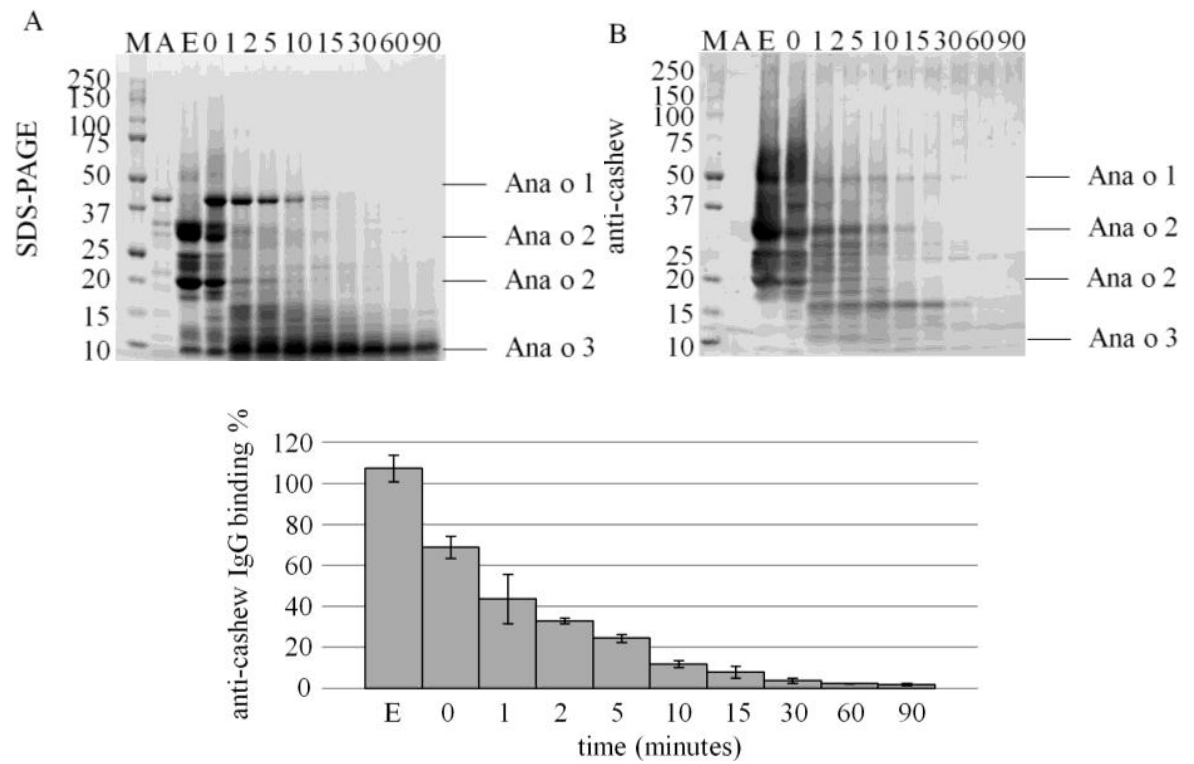

Fig. 2: Treatment of cashew extracts with ASP reduces antibody binding of cashew allergens. Cashew extract samples [10 $\mu \mathrm{g}]$ were subjected to digestion with ASP [5 $\mu \mathrm{g}, 4 \mathrm{SAPU} / \mathrm{mg}$ ] and samples of extract harvested and cashew allergen proteins examined by SDS-PAGE [A] and western blot using rabbit antibodies to cashew proteins [B]. Quantitation of binding of rabbit IgG to cashew allergens was performed at the time points illustrated with the mean values of 3 independent tests $+/$ - standard deviation plotted $[\mathrm{C}]$. Lanes: molecular weight markers $[\mathrm{M}]$, ASP $[\mathrm{A}]$, cashew extract $[\mathrm{E}]$, cashew extract with ASP incubation times $[0-90]$ in minutes.

\subsection{Proteolytic treatment of cashew nut flour}

Enzymatic processing has been used to lower $\operatorname{IgE}$ binding to several food allergens. Commercially available aspergillopepsin I/ASP is described as having a $\mathrm{pH}$ optimum of 2.0-3.5 and is marketed as a dietary supplement. We were interested in the ability of this enzyme to degrade cashew proteins at low $\mathrm{pH}$, so we evaluated the ability of ASP to digest cashew nut proteins in vitro under conditions of simulated gastric fluid. Cashew extracts were treated with ASP (76 SAPU/ml) for varying amounts of time and evaluated by SDS-PAGE and immunoblot with rabbit anti-cashew antibody to characterize cashew protein degradation. A significant reduction in the intensity of the ASP 
band during the time course suggested autolysis of the ASP protein, migrating between the 50 and $37 \mathrm{kDa}$ markers, during the assay. Treatment of cashew nut extract with ASP visibly reduced the intensity of the Ana o 1 and Ana o 2 bands on an SDS-PAGE gel (Figure 2A). After only 1 minute, the intensity of Ana o 1 and Ana o 2 bands was decreased, and by 30 minutes they were drastically reduced. Quantification indicated a drop in the intensity of the $50 \mathrm{kDa}$ Ana o 1 band of $70 \%$ by 1 minute and $95 \%$ by 30 minutes. Likewise, the intensity of the $32 \mathrm{kDa}$ and $20 \mathrm{kDa}$ Ana o 2 bands were decreased $70 \%$ at 1 minute and $97 \%$ at 30 minutes. During this time there was a corresponding increase in the size and intensity of a diffuse band migrating near the $10 \mathrm{kDa}$ marker. This band is presumably composed of peptide fragments from larger cashew proteins, and it obscured visualization of the Ana o 3 band also migrating near the $10 \mathrm{kDa}$ marker. To verify proteolysis of the Ana o proteins, we probed the ASP treated cashew extracts with rabbit anti-cashew antibodies on a western blot and found a corresponding decrease in immunoreactivity with cashew proteins (Figure 2B). We quantified rabbit IgG binding to the cashew allergens. Following 10 minutes of treatment of cashew allergens with ASP, the IgG binding of cashew allergens had been reduced to less than $20 \%$. By 30 minutes of treatment with ASP, the binding of IgG to cashew allergens was lowered to less than $5 \%$ (Figure 2C).

\subsection{IgE binding to proteolytically treated cashew nut extract}

To test IgE binding to cashew allergens we incubated the ASP treated cashew extracts in a competitive ELISA with a pool of serum obtained from 8 individuals with cashew allergy. We compared IgE binding to the ASP treated extract with both undigested control and porcine pepsin treated extract. Porcine pepsin treated cashew extract has been demonstrated to have lowered IgE binding in vitro [24, 25]. Both the pepsin and ASP treated cashew extracts exhibited reduced $\operatorname{IgE}$ binding in the competitive ELISA compared to the control extract (Figure 3A). While pepsin treatment of the extracts noticeably shifted the binding curve, the ASP treated extract reduced binding capacity of the extracts over 10 fold at $50 \%$ binding as compared to the undigested control. Binding to pooled sera can be misleading due to uneven contributions from dominant serum samples, so we chose 5 of the sera to individually evaluate $\operatorname{IgE}$ binding to ASP treated extracts.

In nearly every case, the ASP-induced degradation of cashew proteins resulted in a reduction of $\operatorname{IgE}$ binding to the treated sample in comparison to both the pepsin treated and control extract (Figure 3B).

The values for the ASP treated extract varied, but in 3 of the 5 samples (patients 1, 3, and 4) we observed a greater than $20 \%$ reduction in IgE binding compared to the control. While the effect was less pronounced, IgE binding to the ASP treated extract from patients 2 and 5 sera was reduced $5 \%$ and $15 \%$, respectively. These results using individual serum samples are consistent with IgE binding from pooled serum samples and rabbit anti-cashew IgG binding to cashew proteins. The data collectively suggest that continued study of ASP enzymes as reagents in tree nut and peanut allergen processing steps is warranted. Binding to pooled sera can
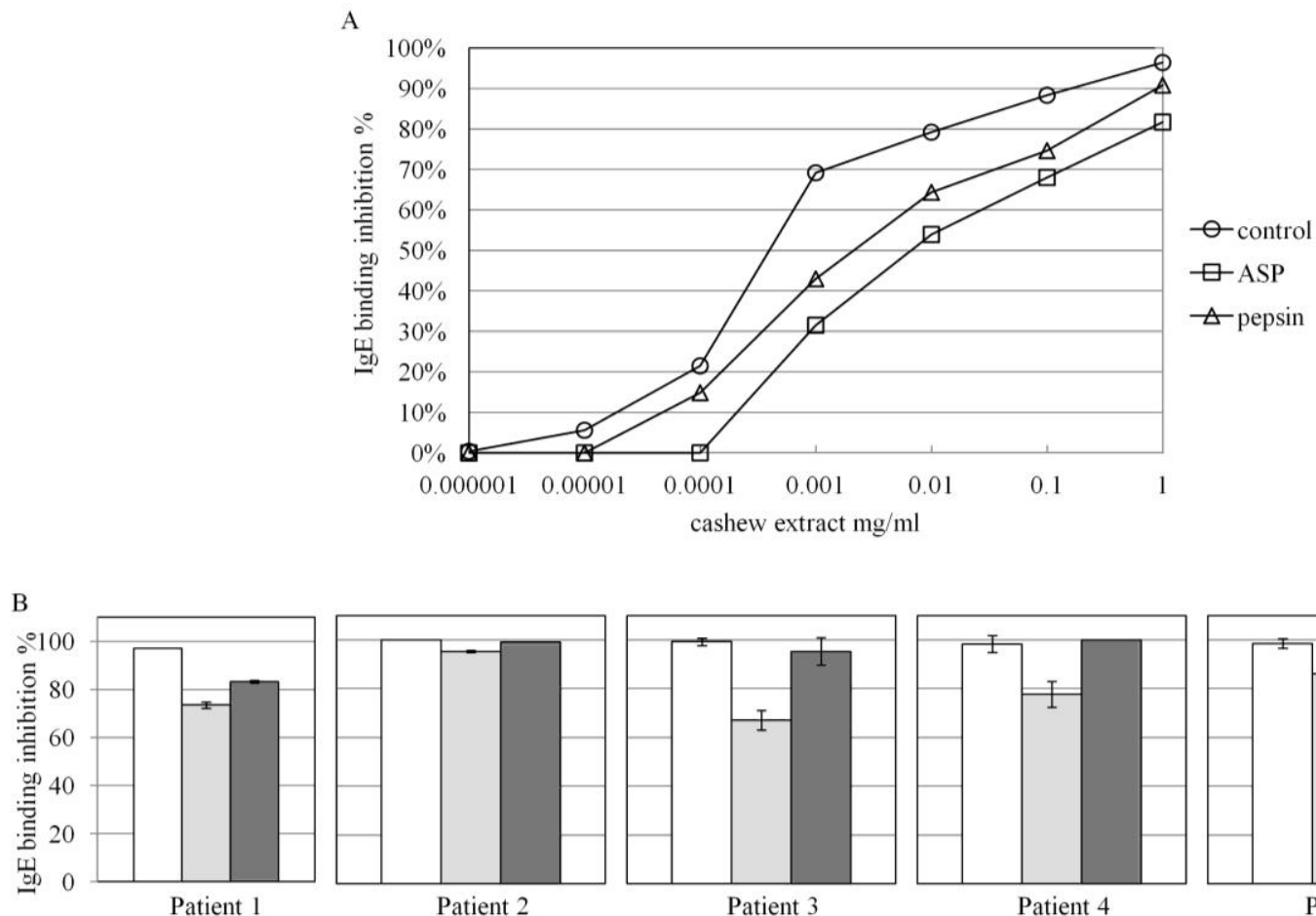

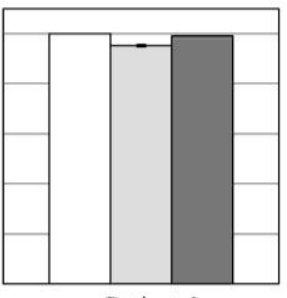

Patient 2

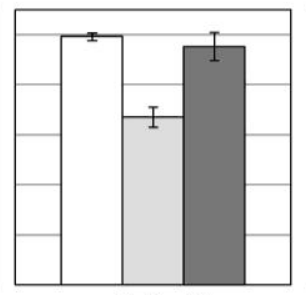

Patient 3

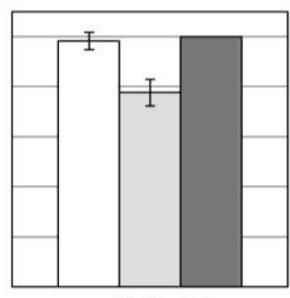

Patient 4

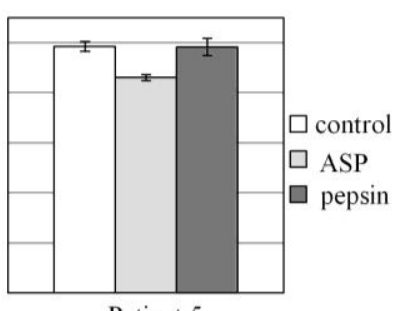

Patient 5

Fig. 3: Treatment of cashew nut extracts with ASP or pepsin reduces IgE binding of cashew nut allergens. Pooled serum from 8 patients with cashew nut allergies was analyzed for competitive IgE binding of cashew allergens following treatment with ASP or pepsin [A] and plotted data are representative of 2 independent repetitions. Five individual patient serum samples were examined for IgE binding using competitive ELISA with 0.1 mg/ml cashew allergen proteins following treatment with ASP or pepsin [B]. 
be misleading due to uneven contributions from dominant serum samples, so we chose 5 of the sera to individually evaluate $\operatorname{IgE}$ binding to ASP treated extracts. In nearly every case, the ASPinduced degradation of cashew proteins resulted in a reduction of $\mathrm{IgE}$ binding to the treated sample in comparison to both the pepsin treated and control extract (Fig 3B).

\section{DISCUSSION}

Our analysis indicates that an aspergillopepsin I/acid stable protease (ASP) is secreted by fungi in the genus Aspergillus following growth on media containing cashew flour. We have identified an ASP I enzyme produced by A. niger that degrades cashew nut proteins and reduced antibody binding of the allergen proteins under simulated gastric fluid conditions in vitro. The ASP enzymes have been previously characterized as secreted proteins from A. niger [36], A. fumigatus [29], and A. oryzae [37]. Aspergillopepsins require aspartic and glutamic acid residues for catalytic activity [38, 39] and two forms of ASP are generated ASP I and ASP II [40, 41]. ASP I (GI 134081775) is a pepsin-type aspartic proteinase with a predicted molecular weight of $41 \mathrm{kDa}$, that is active within a range of $\mathrm{pH} 2.0$ to 4.0, and can be inhibited by pepstatin [26, 42, 43]. In contrast, ASP II (GI 134054586) is a non-pepsin-type acid proteinase, with a predicted molecular weight of $30 \mathrm{kDa}$, that is active in a $\mathrm{pH}$ range between $\mathrm{pH} 2.0$ to 3.0 and is resistant to pepsin-type aspartic proteinases inhibitors such as pepstatin $[42,44,45]$. Despite the differences in size and inhibitor sensitivity, both ASP enzymes can be irreversibly inactivated above $\mathrm{pH} 6.0$ [46]. The stability and activity of ASP enzymes at low $\mathrm{pH}$ make the proteins attractive targets for commercial development for the enzymatic processing of cashew allergens.

ASP enzymes are commercially available proteases that have been used in many applications including degradation of haze forming wine proteins [47] and enhancement of gluten degradation within simulated gastric digestion conditions [48]. While we did not purify the ASP I enzyme from A. niger, we utilized a commercially available ASP enzyme to determine if ASP I could hydrolyze cashew allergens. Under our assay conditions, the commercial ASP enzyme appeared to be unstable and may have undergone autolysis. We used these conditions to mimic gastric digestion, and future research could be directed towards the development of recombinant proteases such as ASP with increased stability under gastric conditions. Despite this reduction in the amount of active ASP enzyme, we observed hydrolysis of the cashew extract proteins into lower molecular weight peptides. Hydrolysis of the cashew proteins produced a diffuse band that formed at approximately $10 \mathrm{kDa}$. Degradation of Ana o 1 and Ana o 2 by the ASP I enzyme into lower molecular weight forms was apparent from SDS-PAGE analysis and confirmed by western blot analysis using a rabbit anti-cashew IgG antibody. While our results indicate that ASP enzyme may be utilized for degradation of cashew allergen proteins, the degraded products may still induce an allergic response. As such we performed experiments to determine if the hydrolyzed cashew allergen proteins could be bound by the IgE antibody in serum samples taken from patients with a cashew allergy. Treatment of the pooled serum samples resulted in a greater than 10 fold decrease in IgE binding capacity to cashew extract proteins. We observed a reduction in IgE binding of cashew allergen proteins following incubation with 5 individual patient serum samples. Overall, our in vitro assays demonstrated a reduction in IgE to cashew allergens following ASP treatment, and our results are consistent with previous findings demonstrating that proteolysis can attenuate $\mathrm{IgE}$ binding to peanut and tree nut allergens [21-25].

\section{CONCLUSION}

Based upon our findings, continued efforts to characterize ASP proteins as food allergen processing enzymes are warranted for the identification of novel methods of food allergenicity attenuation. Experiments to confirm the direct hydrolysis of cashew allergen proteins and testing the efficacy of the proteins at reducing IgE binding of the allergens using mouse model systems are necessary next steps in validating the usefulness of ASP enzymes in attenuating cashew allergens. Studies investigating the structure-function relationship of the ASPs would also be useful for the design a more robust enzyme that is stable under gastric conditions and exhibits reduced autolysis. Incorporation of ASPs optimized for the gastric environment could have a multitude of nutritional and medical applications.

The global market for food and feed enzymes is a multibillion-dollar industry [49, 50]. Enzymatic processing methods are widely used and collectively comprise an essential tool in the food-processing arena. Members of the Aspergillus genus are widely used in the food industry for food processing, are metabolically diverse and known to vary gene expression in response to changes in culture conditions [30]. As such Aspergilli are good targets for the identification of novel enzymes and enzyme complexes that can be mass produced and used to modify or degrade nut allergens so that the proteins are no longer able to induce an allergic reaction.

\section{ACKNOWLEDGMENTS}

We would like to thank Vincent Streva and Yvette BrenMattison for helpful discussion and critical evaluation of the material presented. This research was supported by funds from the U.S. Department of Agriculture-Agricultural Research Service, the Allergy Partners of North Texas Research, and CBD was supported by NIH RCMI \#8G12MD007595 and P20GM103424. Mention of trade names, commercial products, or companies in this article is solely for the purpose of providing specific information and does not imply recommendation or endorsement by the U.S. Department of Agriculture. 


\section{REFERENCES}

1. Gupta RS, Springston EE, Warrier MR, Smith B, Kumar R, Pongracic J, Holl JL. The prevalence, severity, and distribution of childhood food allergy in the United States. Pediatrics 2011; 128: e9-17.

2. Sicherer SH, Munoz-Furlong A, Godbold JH, Sampson HA. US prevalence of self-reported peanut, tree nut, and sesame allergy: 11year follow-up. J Allergy Clin Immunol 2010; 125: 1322-6.

3. Fleischer DM. The natural history of peanut and tree nut allergy. Curr Allergy Asthma Rep 2007; 7: 175-81.

4. Bock SA, Munoz-Furlong A, Sampson HA. Fatalities due to anaphylactic reactions to foods. J Allergy Clin Immunol 2001; 107: 191-3.

5. Bock SA, Munoz-Furlong A, Sampson HA. Further fatalities caused by anaphylactic reactions to food, 2001-2006. J Allergy Clin Immunol 2007; 119: 1016-8.

6. Blumchen K, Beder A, Beschorner J, Ahrens F, Gruebl A, Hamelmann E, Hansen G, Heinzmann A, Nemat K, Niggemann B, Wahn U, Beyer $\mathrm{K}$. Modified oral food challenge used with sensitization biomarkers provides more real-life clinical thresholds for peanut allergy. J Allergy Clin Immunol. 2014; 134: 390-398.

7. Klein Entink RH, Remington BC, Blom WM, Rubingh CM, Kruizinga AG, Baumert JL, Taylor SL, Houben GF. Food allergy population thresholds: An evaluation of the number of oral food challenges and dosing schemes on the accuracy of threshold dose distribution modeling. Food Chem Toxicol. 2014; 70: 134-143.

8. Sampson HA, Anaphylaxis and emergency treatment. Pediatrics 2003; 111: 1601-8.

9. Clark S, Espinola J, Rudders SA, Banerji A, Camargo CA, Jr. Frequency of US emergency department visits for food-related acute allergic reactions. J Allergy Clin Immunol. 2011; 127: 682-3.

10. Herbert LJ, Dahlquist LM, Perceived history of anaphylaxis and parental overprotection, autonomy, anxiety, and depression in food allergic young adults. J Clin Psychol Med Settings. 2008; 15: 261-9.

11. Bollinger ME, Dahlquist LM, Mudd K, Sonntag C, Dillinger L, McKenna K. The impact of food allergy on the daily activities of children and their families. Ann Allergy Asthma Immunol. 2006; 96: 415-21.

12. Gupta R, Holdford D, Bilaver L, Dyer A, Holl JL, Meltzer D. The economic impact of childhood food allergy in the United States. JAMA Pediatr. 2013; 167: 1026-31.

13. Kim EH, Burks W. Immunological basis of food allergy [IgEmediated, non-IgE-mediated, and tolerance]. Chem Immunol Allergy. 2015; 101: 8-17.

14. Davoren M, Peake J. Cashew nut allergy is associated with a high risk of anaphylaxis. Arch Dis Child. 2005; 90: 1084-5.

15. Clark, AT, Anagnostou K, Ewan PW. Cashew nut causes more severe reactions than peanut: case-matched comparison in 141 children. Allergy. 2007; 62: 913-6.

16. Wang F, Robotham JM, Teuber SS, Tawde P, Sathe SK, Roux KH. Ana o 1, a cashew [Anacardium occidental] allergen of the vicilin seed storage protein family. $J$ Allergy Clin Immunol. 2002; 110: 160-6.

17. Wang F, Robotham JM, Teuber SS, Sathe SK, Roux KH. Ana o 2, a major cashew [Anacardium occidentale L.] nut allergen of the legumin family. Int Arch Allergy Immunol. 2003; 132: 27-39.

18. Robotham JM, Wang F, Seamon V, Teuber SS, Sathe SK, Sampson HA, Beyer K, Seavy M, Roux KH. Ana o 3, an important cashew nut [Anacardium occidentale L.] allergen of the $2 \mathrm{~S}$ albumin family. $\mathrm{J}$ Allergy Clin Immunol. 2005; 115: 1284-90.

19. Su M, Venkatachalam M, Teuber SS, Roux KH, Sathe SK. Impact of g-irradiation and thermal processing on the antigenicity of almond, cashew nut, and walnut proteins. J Sci Food Agric. 2004; 84: 1119-25.

20. Venkatachalam M, Monaghan EK, Kshirsagar HH, Robotham JM, O'Donnell SE, Gerber MS, Roux KH, Sathe SK. Effects of processing on immunoreactivity of cashew nut [Anacardium occidentale L.] seed flour proteins. J Agric Food Chem. 2008; 56: 8998-9005.

21. Shi X, Guo R, White BL, Yancey A, Sanders TH, Davis JP, Burks AW, Kulis M. Allergenic properties of enzymatically hydrolyzed peanut flour extracts. Int Arch Allergy Immunol. 2013; 162: 123-30.
22. Li H, Yu J, Ahmedna M, Goktepe I. Reduction of major peanut allergens Ara $\mathrm{h} 1$ and Ara $\mathrm{h} \mathrm{2}$, in roasted peanuts by ultrasound assisted enzymatic treatment. Food Chem. 2013; 141: 762-8.

23. Yu J, Ahmedna M, Goktepe I, Cheng H, Maleki S. Enzymatic treatment of peanut kernels to reduce allergen levels. Food Chemistry. 2011; 127: 1014-22.

24. Kulis M, Macqueen I, Li Y, Guo R, Zhong XP, Burks AW. Pepsinized cashew proteins are hypoallergenic and immunogenic and provide effective immunotherapy in mice with cashew allergy. J Allergy Clin Immunol. 2012; 130: 716-23.

25. Mattison CP, Grimm CC, Wasserman RL. In vitro digestion of soluble cashew proteins and characterization of surviving IgE-reactive peptides. Mol Nutr Food Res. 2014; 58: 884-893.

26. Rao MB, Tanksale AM, Ghatge MS, Deshpande VV. Molecular and biotechnological aspects of microbial proteases. Microbiol Mol Biol Rev. 1998; 62: 597-635.

27. Freire FC, Kozakiewicz Z, Paterson RR. Mycoflora and mycotoxins of Brazilian cashew kernels. Mycopathologia. 1999; 145: 95-103.

28. Midorikawa GE, Pinheiro MR, Vidigal BS, Arruda MC, Costa FF, Pappas GJ Jr, Ribeiro SG, Freire F, Miller RN. Characterization of Aspergillus flavus strains from Brazilian Brazil nuts and cashew by RAPD and ribosomal DNA analysis. Lett Appl Microbiol. 2008; 47: 12-8.

29. Schwienbacher M, Weig M, Thies S, Regula JT, Heesemann J, Ebel F. Analysis of the major proteins secreted by the human opportunistic pathogen Aspergillus fumigatus under in vitro conditions. Med Mycol. 2005: 43: 623-30.

30. Duran RM, Gregersen S, Smith TD, Bhetariya PJ, Cary JW, HarrisCoward PY, Mattison CP, Grimm C, Calvo AM. The role of Aspergillus flavus veA in the production of extracellular proteins during growth on starch substrates. Appl Microbiol Biotechnol. 2014; 98: 5081-94.

31. Monod M, Togni G, Rahalison L, Frenk E. Isolation and characterisation of an extracellular alkaline protease of Aspergillus fumigatus. J Med Microbiol. 1991; 35: 23-8.

32. Bouchara JP, Larcher G, Joubaud F, Penn P, Tronchin G, Chabasse D. Extracellular fibrinogenolytic enzyme of Aspergillus fumigatus: substrate-dependent variations in the proteinase synthesis and characterization of the enzyme. FEMS Immunol Med Microbiol. 1993; 7: 81-91.

33. Kroon PA, Faulds CB, Williamson G. Purification and characterization of a novel esterase induced by growth of Aspergillus niger on sugar-beet pulp. Biotechnol Appl Biochem. 1996; 23 [Pt 3]: 255-62.

34. Mattison CP, Desormeaux WA, Wasserman RL, Yoshioka-Tarver M, Condon B, Grimm CC. Decreased Immunoglobulin E [IgE] Binding to Cashew Allergens following Sodium Sulfite Treatment and Heating. J Agric Food Chem. 2014; 62: 6746-55.

35. Revision UCo. The United States Pharmacopeia - The National Formulary. In The United States Pharmacopeial Convention, Inc. 1990; Vol. USP XXII: 1788 -1789.

36. Koaze Y, Goi H, Ezawa KYY, Hara T. Fungal proteolytic enzymes. Part I. Isolation of two kinds of acid-proteases excreted by Aspergillus niger var. macrosporus. Agricultural and Biological Chemistry. 1964; 28: 216-223.

37. Zhu LY, Nguyen CH, Sato T, Takeuchi M. Analysis of secreted proteins during conidial germination of Aspergillus oryzae RIB40. Biosci Biotechnol Biochem. 2004; 68: 2607-12.

38. Huang XP, Kagami N, Inoue H, Kojima M, Kimura T, Makabe O, Suzuki K, Takahashi K. Identification of a glutamic acid and an aspartic acid residue essential for catalytic activity of aspergillopepsin II, a non-pepsin type acid proteinase. J Biol Chem. 2000; 275:26607-14.

39. Shintani T, Kobayashi M, Ichishima E. Characterization of the S1 subsite specificity of aspergillopepsin I by site-directed mutagenesis. J Biochem. 1996; 120: 974-81.

40. Inoue H, Hayashi T, Huang XP, Lu JF, Athauda SB, Kong KH, Yamagata $\mathrm{H}$, Udaka S, Takahashi $\mathrm{K}$. Heterologous expression and site-directed mutagenesis studies on the activation mechanism and the 
roles of the basic residues in the prosegment of aspergillopepsinogen I. Eur J Biochem. 1996; 237: 719-25.

41. Inoue H, Huang XP, Hayashi T, Athauda SB, Yamagata H, Udaka S, Takahashi $\mathrm{K}$. The roles of the basic residues in the prosegment of aspergillopepsinogen I. Adv Exp Med Biol. 1998; 436: 239-44.

42. Aoyagi T, Kunimoto S, Morishima H, Takeuchi T, Umezawa $\mathrm{H}$. Effect of pepstatin on acid proteases. J Antibiot [Tokyo]. 1971; 24: 687-94.

43. Koaze Y, Goi HEK, Yamada Y, Hara T. Fungal Proteolytic Enzymes: Part I. Isolation of two Kinds of Acid-proteases Excreted by Aspergillus niger var. macrosporus. Agricultural and Biological Chemistry. 1964; 28: 216-223.

44. Chang WJ, Horiuchi S, Takahashi K, Yamasaki M, Yamada Y. The structure and function of acid proteases. VI. Effects of acid proteasespecific inhibitors on the acid proteases from Aspergillus niger var. macrosporus. J Biochem. 1976: 80: 975-81.

45. Maeda M, Takeuchi K, Kojima M, Tanokura M, Kimura K, Amemiya $\mathrm{Y}$, Kihara $\mathrm{H}$, Takahashi K. Kinetic studies of unfolding process of aspergillopepsin II by $\mathrm{pH}$-jump methods. Biochem Biophys Res Commun. 2003; 301: 745-50.

46. Fukada HTK, Sorai MKM, Tanokura M, Takahashi K. Differential scanning colourimetric studies of the thermal unfolding of acid proteinase A from Aspergillus niger at various pHs. Thermochimica Acta. 1995; 267: 373-378.
47. Marangon M, Van Sluyter SC, Robinson EM, Muhlack RA, Holt HE, Haynes PA, Godden PW, Smith PA, Waters EJ. Degradation of white wine haze proteins by Aspergillopepsin I and II during juice flash pasteurization. Food Chem. 2012; 135: 1157-65.

48. Ehren J, Moron B, Martin E, Bethune MT, Gray GM, Khosla C. A food-grade enzyme preparation with modest gluten detoxification properties. PLoS One. 2009; 4: e6313.

49. Fernandes P. Enzymes in food processing: a condensed overview on strategies for better biocatalysts. Enzyme Res. 2010; 2010: 862537.

50. Gavrilescu M, Chisti Y. Biotechnology-a sustainable alternative for chemical industry. Biotechnol Adv. 2005; 23: 471-99.

\section{How to cite this article:}

DeFreece CB, Cary JW, Grimm CC, Wasserman RL, Mattison CP. Treatment of cashew extracts with Aspergillopepsin reduces IgE binding to cashew allergens. J App Biol Biotech. 2016; 4 (02): 001-010. DOI: 10.7324/JABB.2016.40201 